University of Chicago Law School

Chicago Unbound

Journal Articles

Faculty Scholarship

1981

\title{
The Next Step in the Antitrust Treatment of Restricted \\ Distribution: Per Se Legality
}

Richard A. Posner

Follow this and additional works at: https://chicagounbound.uchicago.edu/journal_articles

Part of the Law Commons

\section{Recommended Citation}

Richard A. Posner, "The Next Step in the Antitrust Treatment of Restricted Distribution: Per Se Legality," 48 University of Chicago Law Review 6 (1981).

This Article is brought to you for free and open access by the Faculty Scholarship at Chicago Unbound. It has been accepted for inclusion in Journal Articles by an authorized administrator of Chicago Unbound. For more information, please contact unbound@law.uchicago.edu. 


\title{
The Next Step in the Antitrust Treatment of Restricted Distribution: Per Se Legality
}

\author{
Richard A. Posner †
}

The Supreme Court's standard for evaluating the legality of restricted distribution has oscillated from the Rule of Reason to per se illegality and back. ${ }^{1} \mathrm{I}$ argue in this article that it is time to adopt an entirely new standard, namely, per se legality.

\section{INTRODUCTION}

By "restricted distribution" I mean a marketing system in which the manufacturer places restrictions on competition among the distributors or dealers that provide its goods either to lower links in the chain of distribution or to the ultimate consumer. Such restrictions take many forms. One is resale price maintenance, whereby price competition (or sometimes price gouging) is forbidden. Another is the assignment of exclusive sales territories, which forbid the distributor or dealer to sell outside of a specified territory on pain of having its relationship with the manufacturer terminated or, perhaps, of having to pay a "profit passover" or some other charge to the distributor or dealer whose territory it invaded. In addition, there are outlet restrictions, which might forbid a distributor to sell to any dealer not approved by the manufacturer, or forbid one dealer to sell ("bootleg") to another dealer, and location clauses, which forbid a dealer to sell the manufacturer's product at any location other than that specified in the dealership agreement. Sometimes a manufacturer will reserve certain large customers to itself, thus eliminating the competition that might otherwise exist between itself and its dealers. Or it may agree to an exclusive distributorship or dealership, and thereby lose its freedom to author-

$\dagger$ Lee and Brena Freeman Professor of Law, The University of Chicago. Frank Easterbrook, William Landes, Peter Linneman, and Robert Sherwin commented helpfully on a previous draft of this paper.

Compare White Motor Co. v. United States, 372 U.S. 253 (1963) and Continental T.V., Inc. v. GTE Sylvania Inc., 433 U.S. 36 (1976) with United States v. Arnold, Schwinn \& Co., 388 U.S. 365 (1967). 
ize additional distributors or dealers that might compete with the one previously authorized.

All of the restrictions just noted limit or, more precisely, alter or channel intrabrand competition between distributors of a single brand. Manufacturers sometimes restrict interbrand competition by their distributors and dealers as well as intrabrand competition. For example, a manufacturer may require its distributors or dealers to stock and promote its full line of products, a practice sometimes attacked as "full-line forcing," or tying;" the restriction is not on competition in the distribution of one brand, but on competition between the manufacturer's brand and other brands that the distributors or dealers might carry in preference to it in the absence of the full-line requirement. Another example of a restriction on interbrand competition in distribution is the exclusive dealing agreement, whereby the distributor or dealer agrees not to handle the products of a competing manufacturer.

This article discusses only restrictions on intrabrand competition. More particularly, it is addressed to restrictions on such competition among distributors or dealers, as distinct from customer reservations by the manufacturer, which limit competition between the distributors or dealers on the one hand and the manufacturer on the other. I shall also ignore the exclusive distributorship or dealership. For some reason, this type of restriction on intrabrand competition has been relatively uncontroversial in antitrust law. Such arrangements are usually, although not invariably, upheld. ${ }^{3}$

Restrictions on distribution are subject to section 1 of the Sherman Act, ${ }^{4}$ which forbids agreements in restraint of trade. Three years ago, in Continental T.V., Inc. v. GTE Sylvania Inc., the Supreme Court held that vertical restrictions on distribution of the kind I shall be discussing here, other than resale price maintenance, were to be judged under the Rule of Reason; they were not, despite the Court's holding to the contrary ten years earlier in United States v. Arnold, Schwinn \& Co., ${ }^{\circ}$ illegal per se. As we shall see, the Rule of Reason is an amorphous standard that requires or at least permits the antitrust adjudicator to make a

2 See, e.g., Heatransfer Corp. v. Volkswagenwerk, A.G., 553 F.2d 694 (5th Cir. 1977), cert. denied, 434 U.S. 1087 (1978).

3 For a recent discussion, see Comment, Vertical Agreement as Horizontal Restraint: Cernuto, Inc. v. United Cabinet Corp., 128 U. PA. L. REv. 622, 630-31, 642-44 (1980).

15 U.S.C. $\$ 1$ (1976).

s 433 U.S. 36 (1977).

- 388 U.S. 365 (1967). 
broad-ranging assessment of all competitive, and perhaps all economic, benefits and costs of the challenged practice. No effort to particularize the standard, either in general or as applied to restricted distribution, was made in Sylvania. The Court may not have realized that decisions in other areas of antitrust law had not made the Rule of Reason a workable standard of decision.

It is now possible to begin to assess the effects of Sylvania by examining the decisions that have applied the Rule of Reason to restricted distribution. Three years is, of course, a short time in the evolution of case law. Enough restricted-distribution cases have been decided in this period, however, to reveal serious problems with the Sylvania decision when it is viewed as a practical guide to judicial decision making.

The problems revealed are threefold. First, the persistence of the per se rule forbidding resale price maintenance warps the judicial approach to nonprice restrictions. Second, the Rule of Reason standard lacks content and so does not provide guidance to judges, juries, or the Federal Trade Commission. Finally, the idea of balancing the (assumed to be anticompetitive)' effects of the restriction on intrabrand competition with the (assumed to be procompetitive) effects of the restriction on interbrand competition-which is the closest thing to a concrete suggestion in Sylvania as to how to apply the Rule of Reason in restricted-distribution cases-is infeasible and unsound.

Besides describing these problems, I offer suggestions for solving them. In particular, refining my previously published recommendations, ${ }^{7}$ I propose that purely vertical restrictions on distribution be declared legal per se.

\section{The Price Exception}

The Court in Sylvania indicated in dictum that resale price maintenance, or vertical price fixing, continues to be illegal per se under section 1 of the Sherman Act. ${ }^{8}$ This is so even though the Court held that exclusive territories, so long as they are vertically imposed, and other nonprice vertical restrictions in distribution

'See Posner, The Rule of Reason and the Economic Approach: Reflections on the Sylvania Decision, 45 U. CHI. L. Rzv. 1 (1977). Rather than attempt to make the present article self-contained, I refer the reader to my Sylvania article for a background discussion of the law and economics of restricted distribution. For a discussion of the cases preceding Syluania, see R. Posner, Antrtrust Law: An Economic Perspective 147-66 (1976).

- 433 U.S. at 51 n.18. 
such as outlet restrictions, are not illegal per se. ${ }^{\ominus}$ This distinction between price and nonprice restrictions is indefensible. ${ }^{10}$ To forbid a dealer or distributor to sell outside of its territory, when it is the only distributor or dealer of the manufacturer's brand in the territory, has if anything a greater adverse effect on intrabrand competition than fixing the price at which it may resell the product. The territorial restriction affects both price and service competition; the price restriction affects only price competition. ${ }^{11}$

Market division and price fixing have always been treated symmetrically in the horizontal context, and they should be so treated in the vertical context as well. ${ }^{12}$ Resale price maintenance is more flexible than exclusive territories as a method of limiting price competition among dealers, and it may be the only feasible method where effective retail distribution requires that dealers be located close to one another; any free-rider or other arguments that are available to justify exclusive territories are equally available to justify resale price maintenance. ${ }^{13}$ Indeed, the free-rider justification of restricted distribution, relied on by the Sylvania Court to overturn Schwinn, ${ }^{14}$ was first advanced in an effort to explain resale price maintenance, rather than exclusive territories. ${ }^{15}$

There are no factors unique to resale price maintenance that justify singling out the practice as per se illegal. The two distinctions relied on by the Sylvania Court ${ }^{16}$ are clearly insufficient. The repeal in 1975 of the fair-trade exemption in the Sherman and Federal Trade Commission Acts ${ }^{17}$ was just that: the repeal of an exemption from the antitrust laws for resale price maintenance conducted in accordance with state fair-trade laws. It was not the enactment of a rule of per se illegality. As for the danger that

- Id. at 57-59.

10 See Posner, supra note 7, at 7-10.

11 I argue below that neither type of restriction really restrains intrabrand competition, when competition for as well as in the market is considered. See text and notes at notes 5557 infra. My point here is simply that resale price maintenance is not more inhibitory of intrabrand competition than exclusive territories are.

${ }^{12}$ This was clearly recognized in Justice Clark's dissenting opinion in White Motor Co. v. United States, 372 U.S. 253, 282 (1963). In White Motor, the Court refused to hold nonprice restrictions in distribution illegal per se.

1s See Posner, Antitrust Policy and the Supreme Court, 76 Colum. L. Rev. 282, 291-93 (1975).

14433 U.S. at 55.

${ }^{16}$ See Telser, Why Should Manufacturers Want Fair Trade?, 3 J.L. \& Econ. 86 (1960).

18 433 U.S. at 51 n.18.

17 Consumer Goods Pricing Act of 1975, Pub. L. No. 94-145, 89 Stat. 801 (1975) (amending 15 U.S.C. $\S \S 1,45$ (a) (1976)). 
resale price maintenance might facilitate cartelization at the manufacturer level, the same danger is presented by exclusive territories. ${ }^{18}$ The Court in Sylvania repudiated one formalistic distinction, that between sale and consignment, ${ }^{19}$ but then apparently adopted another, that between price and nonprice restrictions on competition. $^{20}$

The First Circuit, in Eastern Scientific Co. v. Wild Heerbrugg Instruments, Inc., ${ }^{21}$ apparently found the Sylvania Court's distinction between price and nonprice restrictions on competition in distribution illogical or incomprehensible and so ignored the Court's dictum. In that case the defendant supplier forbade the plaintiff dealer to sell outside of its territory at less than list price. The court upheld this price restriction, stating:

It may be true that the defendant's policies here appear in form to resemble resale price maintenance agreements. However, we are unable to conceive of how the resale price restrictions used to enforce the assigned territories in the present case can possibly have a greater anticompetitive effect than a pure policy of territorial restrictions. ${ }^{22}$

Upholding an explicit price restriction was an audacious step for a lower court to take. It appears even more so in retrospect, now that the Supreme Court has unanimously, although again in dictum, repeated its view that vertical price fixing is illegal per se. ${ }^{23}$

The facts of the Eastern Scientific case suggest, however, a possible accommodation of the basic logic of Sylvania, which depends on the recognition of the free-rider considerations that justify restrictions on competition in distribution, with the Court's apparent commitment to special treatment of one such restriction, resale price maintenance. The accommodation is to analyze resale price maintenance under the Rule of Reason when it is part of a system of restricted distribution reasonably designed to promote the manufacturer's interest in the efficient distribution of his product. This is not the legal position that I would most prefer to see

18 See Posner, supra note 7, at 7-8.

10 433 U.S. at 53-57.

so Id. at $51 \mathrm{n} .18$.

21572 F.2d 883 (1st Cir.), cert. denied, 439 U.S. 833 (1978).

23 Id. at 885 (footnote omitted) (emphasis in original).

2s California Retail Liquor Dealers Ass'n v. Midcal Aluminum, Inc., 445 U.S. 97, 102-03 (1980) (dictum). 
adopted, ${ }^{24}$ but it is a compromise that would do minimum damage to the precedents, ${ }^{25}$ while simultaneously yielding to the logic of Sylvania where the free-rider considerations are strongest and the effects on intrabrand competition-even intrabrand price competition-are clearly positive. If the defendant in the Eastern Scientific case had imposed an absolute prohibition on sales outside of a dealer's territory, that would have been tantamount to setting a minimum resale price of infinity. By instead allowing dealers to sell outside of their territories at list price, the defendant in effect reduced that infinite price to a finite price at which some sales occurred, and thus increased the amount of intrabrand price competition in its product. In these circumstances, to allow the territorial restriction but prohibit the resale price provision would be perverse indeed.

Another powerful argument for the suggested interpretation of the Eastern Scientific decision is that it is required in order to effectuate the Supreme Court's own policy toward nonprice restrictions. Disparate legal treatment of vertical price and nonprice restrictions may, as a practical matter, often result in the condemnation of the latter as per se illegal, contrary to the holding of Sylvania.

To understand this point, it is necessary to recall that the manufacturer's objective in restricting competition among its dealers or distributors is to induce them to provide greater services to the consumer. ${ }^{28}$ For example, a distributor with an exclusive territory will not stint in providing services that enhance demand for the product out of fear that another distributor will take a free ride on his efforts by selling into the territory that he has cultivated. It is rarely feasible, however, to assign exclusive territories at the retail dealer level. Effective distribution at that level requires that the product be available at numerous proximate outlets, and the closer the outlets are to one another, the more diffcult it is to maintain territorial integrity. In these circumstances, manufacturers typically assign locations rather than territories-that is, they forbid dealers to sell at a location other than

st That position-per se legality for all restrictions on distribution, including resale price maintenance-is advanced in Part $\mathrm{V}$ infra.

${ }^{25}$ These include not only the dicta in Sylvania and Midcal, but also a long line of decisions condemning resale price maintenance as illegal per se, stretching back to $\mathrm{Dr}$. Miles Medical Co. v. John D. Park \& Sons Co., 220 U.S. 373 (1911).

28 The service argument for restricted distribution is set forth in R. POSNER, supra note 7, at 147-51. The argument originated in Telser, supra note 15. 
that specified in the dealership agreement but they do not limit the geographical area from which the dealer can draw customers. Through judicious spacing of dealerships the manufacturer with dealership agreements containing a location clause can limit price competition among its dealers and thereby reduce free riding. It can reinforce the effects of the location clause and dealer spacing by forbidding dealers to sell to other dealers.

These measures, however, individually or combined, will not eliminate the free-rider problem completely. A dealer who forgoes promotional expenditures in order to finance tremendous discounts may be able to draw customers from a large territory by free riding on the promotional efforts of other dealers located throughout that territory. The problem of the "chronic discounter" is every bit as real as that of the "bootlegging" dealer whose transgressions can be prevented, in the aftermath of Sylvania, by enforcing a clause in the dealership agreement forbidding sales to other dealers.

It is unrealistic to expect the manufacturer that uses location clauses and outlet restrictions in order to limit free riding to be indifferent to the dealer that circumvents the intent of the clauses by discounting. As soon as the manufacturer's files contain any correspondence or memoranda documenting its concern, however, it has delivered powerful evidence of per se illegal resale price maintenance into the hands of prospective plaintiffs' lawyers. Any effort, beyond mere exhortation, to terminate, penalize, threaten, or even investigate the discounter may suffice to complete the plaintiff's case under existing-which is to say expansive-interpretations of the meaning of "agreement" under section 1 of the Sherman Act. ${ }^{27}$ Once a dealer is identified as a chronic discounter, he may even be able to violate lawful provisions of the dealership agreement with impunity, because the enforcement of any provisions against it may be deemed to have been motivated by its discounting. The taint of price fixing may invalidate the entire system of restricted distribution.

That these concerns are not merely hypothetical is shown by two recent cases, the Third Circuit's decision in Cernuto, Inc. v. United Cabinet Corp.,$^{28}$ and the district court decision in Eiberger

${ }_{27}$ See, e.g., Albrecht v. Herald Co., 390 U.S. 145 (1968); United States v. Parke, Davis \& Co., 362 U.S. 29 (1960); Yentsch v. Texaco, Inc., 630 F.2d 46 (2d Cir. 1980); Clairol, Inc. v. Boston Discount Center of Berkley, Inc., 608 F.2d 1114 (6th Cir. 1979).

${ }^{28} 595$ F.2d 164 (3d Cir. 1979). Cernuto is discussed approvingly in Alloy Int'l Co. v. Hoover-NSK Bearing Co., 618 F.2d 110 (7th Cir. 1980). 
v. Sony Corp. of America. ${ }^{29}$ In each case the court indicated that nonprice restrictions in distribution can constitute per se illegal price fixing if they are intended to limit discounting. ${ }^{30}$ Evidence of such motivation would seem to be easily generated where the manufacturer is committed to restricted distribution. For example, in Eiberger there was evidence that many dealers had complained about discounting and that those complaints were behind the warranty charge attacked by the plaintiff. This background suggested to the court that the motivation for the manufacturer's effort to limit discounting was appeasement of the complaining dealers. ${ }^{31}$ Such dealer complaining is likely whenever there is discounting by free riders, because most dealers are harmed by such conduct. The manufacturer cannot prevent the complaining. Yet if it occurs the manufacturer may have to abandon even nonprice restrictions in distribution, because any action it takes against a discounter may be deemed to be tainted by price fixing. ${ }^{32}$

Eiberger suggests a further danger: even if the rule of per se illegality of vertical price restrictions were formally relaxed or abandoned, such restrictions might still be held illegal per se in any case where some horizontal concert among the nondiscounting dealers was proved. ${ }^{33}$ 1980).

20 459 F. Supp. 1276 (S.D.N.Y. 1978), aff'd on other grounds, 622 F.2d 1068 (2d Cir.

so Cernuto was decided on summary judgment, so we have only the plaintiff's allegations. Briefly, these were that its distributorship was terminated not because it failed to provide services or otherwise please the manufacturer but solely because a competing distributor complained to the manufacturer about the plaintiff's pricing. $595 \mathrm{~F} .2 \mathrm{~d}$ at 165 . The Third Circuit held that although the plaintiff could prevail only if the termination was a per se violation of the antitrust laws, such a finding was possible and summary judgment for the defendant therefore was improper. Id. The court explained that the termination might be per se illegal if it was motivated by a desire to maintain resale prices and triggered by a complaint from a competing dealer. Id. at 167-70. In Eiberger the issue was the lawfulness of a warranty charge that Sony had imposed on dealers selling from nonassigned locations. The court found that the warranty charge bore no relationship to the added warranty costs, if any, imposed on Sony (or on other dealers) by these dealers and that in exacting the charge Sony was acting, in part at least, at the behest of dealers complaining of the price competition of the dealers forced to pay these charges. Such conduct amounted to a conspiracy to exclude discounters from the market and as such was per se illegal. $459 \mathrm{~F}$. Supp. at 1284-85.

11459 F. Supp. at $1279-80$.

23 In this connection, the court's remark in Edward J. Sweeney \& Sons, Inc. v. Texaco, Inc., 1979-2 Trade Cas. 79,413, 79,420 (E.D. Pa. 1979), that mere receipt of complaints from dealers is not a basis for an inference of concerted action but that if the manufacturer "acts upon the complaints, thereby becoming more than a passive recipient . . . he turns into a co-conspirator and thereby violates the antitrust laws," is ominous.

ss See 459 F. Supp. at 1284-85. I will consider the problem of horizontal conspiracy 
To summarize, even if the Court's insistence on treating price and nonprice restrictions differently could be rationally defended -as it cannot be-it is overly sophisticated. The businessman who establishes a program of restricted distribution knows that he is hurt by discounting, but he cannot do anything about it directly through resale price restrictions. $\mathrm{He}$ is free to take various indirect steps such as enforcing a location clause, but only if those steps are not motivated by a desire to eliminate existing discounters. The Court's distinction between price and nonprice restrictions has no intuitive meaning to the businessman, and makes his fortunes ever more dependent on whether he, his dealers, and his distributors, have good antitrust lawyers.

\section{The Vacuity of the Rule of Reason}

The Court in Sylvania did not explain how a Rule of Reason trial of a restricted-distribution case should be conducted, perhaps in the belief that the Rule of Reason is a well-defined legal standard. It is not. The authoritative statement of the Rule of Reason remains that of Justice Brandeis in Chicago Board of Trade $v$. United States: ${ }^{\text {s4 }}$

The true test of legality is whether the restraint imposed is such as merely regulates and perhaps thereby promotes competition or whether it is such as may suppress or even destroy competition. To determine that question the court must ordinarily consider the facts peculiar to the business to which the restraint is applied; its condition before and after the restraint was imposed; the nature of the restraint and its effect, actual or probable. The history of the restraint, the evil believed to exist, the reason for adopting the particular remedy, the purpose or end sought to be attained, are all relevant facts. This is not because a good intention will save an otherwise objectionable regulation or the reverse; but because knowledge of intent may help the court to interpret facts and to predict consequences. ${ }^{38}$

This passage invites an unlimited, free-wheeling inquiry. Even if each consideration listed by Justice Brandeis should be viewed simply as an aid to determining whether the alleged restraint of

among dealers in Part $\mathrm{V}$ infra.

s4 246 U.S. 231 (1918).

ss Id. at 238. 
trade is, on balance, substantially anticompetitive-a view implied by Sylvania, ${ }^{36}$ and explicit in the Court's subsequent opinion in National Society of Professional Engineers $v$. United States ${ }^{37}$ - the trier of fact is left in the dark as to how to decide whether a challenged practice is substantially anticompetitive.

The vagueness of the standard might not be an insuperable objection to the Sylvania approach of remitting nonprice vertical restrictions in distribution to decision under the Rule of Reason if antitrust cases were decided by highly experienced and knowledgeable judges specializing in antitrust cases. They are not, however. They are decided by juries consisting of laymen, by the Federal Trade Commission, whose purported expertise in the decision of trade regulation cases is questionable and widely questioned, and by federal district judges, few of whom have much experience in the trial of antitrust cases. These factfinders, jurors especially, have difficulty understanding and applying the Chicago Board of Trade standard, and in weighing the testimony of economic expert witnesses who are hired by plaintiffs and defendants to offer opposite evaluations of the competitive effects of challenged practices. The common practice of including in jury instructions the passage quoted above from the Chicago Board of Trade opinion, often as the only guide to the concept of unreasonable restraint that is offered to the jury, imputes to jurors powers of comprehension that most of them lack.

A standard so poorly articulated and particularized, applied by tribunals so poorly equipped to understand and apply it, places at considerable hazard any restriction that a manufacturer imposes on its dealers and distributors. To be sure, because a Rule of Reason case is more costly to try than a per se case, fewer cases will be brought; furthermore, the probability that the plaintiff will win such a case is of course less than under a rule of per se illegality. ${ }^{38}$ These are advantages of the Rule of Reason compared to the per se rule if one believes, as I do, that most restrictions in distribution promote rather than retard competition. The advantages, however,

se 433 U.S. at 59.

37435 U.S. $679,687-92$ (1978). The case contains an extended but, in my opinion, unhelpful discussion of the Rule of Reason. See Posner, Information and Antitrust: Reflections on the Gypsum and Engineers Decisions, 67 Gzo. L.J. 1187, 1191-92 (1979).

ss This consequence of the Rule of Reason is illustrated by the jury verdict in First Beverages, Inc. v. Royal Crown Cola Co., 612 F.2d 1164 (9th Cir.), cert. denied, 100 S. Ct. 3016 (1980), which exonerated the soft-drink bottlers' territorial restrictions under the Rule of Reason-restrictions found to be illegal by the FTC. See note 40 infra. 
are limited. If the plaintiff overcomes the cost barriers to bringing a Rule of Reason case challenging a scheme of restricted distribution, he has a fair chance to obtain a favorable verdict from the jury or the FTC, given the vagueness of the standard.

Some courts have narrowed the defendant's risk by requiring that the plaintiff in a Rule of Reason case prove substantial market power in a relevant market. ${ }^{30}$ (In practice, this means that the plaintiff must prove that the defendant has a large market share-how large is unclear.) This requirement is a step in the right direction because it excludes a class of cases where restricted distribution cannot possibly impair either interbrand or intrabrand competition. It cannot impair interbrand competition because the defendant lacks substantial market power in the interbrand market, so its distribution practices are unlikely to affect competition in that market. Less obviously, restricted distribution imposed by a defendant without substantial market power cannot impair intrabrand competition either. The absence of market power in the interbrand market implies that the defendant is in competition with firms that sell products regarded by the consumer as close substitutes for the defendant's. The defendant therefore will lose most or all of its sales if its retail price exceeds its competitors' retail price for any reason, including a lack of intrabrand competition that drives its costs of distribution up. To put the point slightly differently, if a firm lacks market power, it cannot affect the price of its product; that price is determined by the market. It may be able to alter the level of services provided with its product, and by so doing alter price. We would not say, however, that a seller of oranges had market power because he sold two oranges for fifty cents, rather than one for twenty-five cents.

To be sure, one can imagine a case in which dealers were fixing the prices of all brands in a market where no brand had a significant market power, and using nominally manufacturer-imposed re-

30 See Gough v. Rossmoor Corp., 585 F.2d 381, 390 (9th Cir. 1978), cert. denied, 440 U.S. 936 (1979); Oreck Corp. v. Whirlpool Corp., 579 F.2d 126, 130 n.5 (2d Cir. 1978) (en banc), cert. denied, 439 U.S. 946 (1979); H\&B Equip. Co. v. International Harvester Co., 577 F.2d 239, 242-43 (5th Cir. 1978); Northwest Power Prods., Inc. v. Omark Indus., Inc., 576 F.2d 83, 90-91 (5th Cir. 1978), cert. denied, 439 U.S. 1116 (1979); Kestenbaum v. Falstaff Brewing Corp., 575 F.2d 564, 571 (5th Cir. 1978), cert. denied, 440 U.S. 909 (1979); George R. Whitten, Jr., Inc. v. Paddock Pool Builders, Inc., 508 F.2d 547, 562 (1st Cir. 1974), cert. denied, 421 U.S. 1004 (1975); Donald B. Rice Tire Co. v. Michelin Tire Corp., 483 F. Supp. 750, 761 (D. Md. 1980). All of these cases except Gough and Whitten involved restrictions in distribution. 
strictions to police their price-fixing agreement. This would be a case of horizontal price fixing by dealers, however, and therefore would be illegal per se even if vertical restrictions in distribution were beyond the reach of the antitrust laws.

To require that market power be shown in the product market in which the defendant competes is a salutary step, but a small one. Relevant-market definition in antitrust cases is uncertain; in many cases a plaintiff may be able to persuade the factfinder to define a market in which the defendant has a substantial share. Further, there is no agreement as to how great the defendant's market share must be to satisfy the threshold condition of substantial market power. Finally, this approach has been vigorously resisted by the FTC, ${ }^{40}$ by the Second Circuit in Eiberger, ${ }^{41}$ and by the Third Circuit as well. ${ }^{42}$

It is hard to discern, in the years since Sylvania was decided, net progress in applying the Rule of Reason to restricted-distribution cases. Authority is divided, seemingly even within the Second Circuit, ${ }^{43}$ as to whether there is a threshold requirement of market power. On other questions pertaining to the application of the Rule of Reason in distribution cases, the analysis remains where it was in 1977.4 Some decisions, notably the decision on remand in Sylvania ${ }^{45}$ and the recent district court decision in Donald B. Rice

40 See Coca-Cola Co., [1976-1979 Transfer Binder] Trade Reg. Rep. (CCH) I 21,509, at 21,570 (F.T.C. 1978). Congress recently reversed the Coca-Cola decision by passing a statute that authorizes soft-drink syrup manufacturers to impose exclusive territories on their bottlers so long as there is "substantial and effective interbrand competition." Soft Drink Interbrand Competition Act, Pub. L. No. 96-308, § 2, 96 Stat. 939 (1980).

42 Eiberger v. Sony Corp. of Am., 622 F.2d 1068 (2d Cir. 1980).

12 See Harold Friedman Inc. v. Thorofare Mkts. Inc., 587 F.2d 127 (3d Cir. 1978), where the court stated:

The reasonableness of any anticompetitive conduct may be judged only after careful consideration of the effect it will have on competition. The purpose of such activity, the structure of the industry, and the strength of competition in the relevant geographic and product markets are among the factors that generally mold the outcome of such analysis. Of course, no single aspect is dispositive. Also, conclusions reached by courts in one context are not necessarily applicable in another.

Id. at 141 (footnote omitted).

4s Compare Eiberger v. Sony Corp. of Am., 622 F.2d 1068 (2d Cir. 1980) with Oreck Corp. v. Whirlpool Corp., 563 F.2d 54 (2d Cir. 1977) (panel opinion), cert. denied, 439 U.S. 946 (1978).

4 One court has stated explicitly that, for restricted-distribution cases, Sylvania ratified the Chicago Board of Trade formulation of the Rule of Reason. First Beverages, Inc. v. Royal Crown Cola Co., 612 F.2d 1164, 1170-71 (9th Cir.), cert. denied, 100 S. Ct. 3016 (1980).

4s Continental T.V., Inc. v. GTE Sylvania Inc., 461 F. Supp. 1046 (N.D. Cal. 1978). 
Tire Co. v. Michelin Tire Corp., ${ }^{46}$ evince strong sympathy for freerider justifications of restricted distribution. Others, notably Eiberger ${ }^{47}$ and Coca-Cola Co., ${ }^{48}$ do not. ${ }^{49}$ There is no rule for deciding such cases, however. There is only a checklist of factors to which different triers of fact give different weights. Professor Pitofsky's description of the Rule of Reason at the time of the Sylvania decision remains apt:

There is no existing analytical framework for applying a rule of reason generally, and certainly none for applying it to non-price vertical restraints. The technique of the Sylvania majority-quoting a long list of factors without any indication of priority or weight to be accorded each factor-unfortunately is standard operating procedure. ${ }^{50}$

\section{Balancing Interbrand and Intrabrand Competition}

A superficially appealing but illusory route toward a more definite standard of legality is suggested by the glancing reference in Sylvania to "balancing" interbrand and intrabrand competition." The FTC in the Coca-Cola case ${ }^{62}$ and the Second Circuit in Eiberger $^{\text {53 }}$ elevated the discussion to a rule: balance any positive effect of restricted distribution on interbrand competition against its negative effect on intrabrand competition, and decide the case according to which way the balance inclines. ${ }^{54}$

In my opinion, the proponents of this approach make two mistakes. The first is to think that it is straightforward to determine whether a restriction is on balance procompetitive or anticompeti-

46 483 F. Supp. 750 (D. Md. 1980). See also Golden Gate Acceptance Corp. v. General Motors Corp., 597 F.2d 676, 678 n.4 (9th Cir. 1979).

4759 F. Supp. at 1282.

48 [1976-1979 Transfer Binder] Trade REg. REP. (CCH) at 21,574-75.

10 In addition, the FTC staff is extremely hostile to Sylvania, and apparently is considering bringing a series of test cases designed to apply a rule of per se illegality to many types of vertical restrictions on distribution, including some nonprice restrictions. See FTC Considering Test Cases on Manufacturers' Pricing Practices, 968 Antitrust \& Trade Reg. REP. (BNA) A-20 (1980).

so Pitofsky, The Sylvania Case: Antitrust Analysis of Non-Price Vertical Restrictions, 78 Colum. L. REv. 1, 34 (1978) (footnote omitted).

${ }^{61}$ See 433 U.S. at 57 n.27. The Court did not say that such balancing was the right way to apply the Rule of Reason, but only that it was not impermissibly subjective.

${ }_{83}$ [1976-1979 Transfer Binder] Trade REg. REP. (CCH) at 21,579.

63 622 F.2d at 1075-76.

s4 For a recent and complex elaboration of the rule, see Zelek, Stern \& Dunfee, A Rule of Reason Decision Model After Sylvania, 68 Calir. L. Rev. 13 (1980). 
tive. The second is to ignore the fact that the market automatically trades off intrabrand and interbrand competition and yields the combination of the two that maximizes social wealth.

To understand the first mistake, compare two distribution systems, of manufacturers $A$ and $B$ respectively. $A$ does not impose any restrictions on the distribution of its product. As a result, its dealers and distributors provide little or no information or other services with the product, and its retail price is therefore low. $B$ does impose restrictions; its dealers, therefore, do provide extensive services, and the retail price of its product is higher. In which distribution system is there more competition? In $A$ 's, because prices are lower, or in $B$ 's, because services are greater? ${ }^{\text {os }}$ If competition is defined simply as rivalry, rather than as a device for maximizing consumer welfare or economic efficiency, there is no way to answer such questions, save by an arbitrary preference for price over service competition, or for the reverse. To be sure, the Supreme Court has said that price is "the central nervous system of the economy,"ss and has condemned any "interference with the setting of price by free market forces." however, is not the equivalent of a considered view that price competition is more important than service competition and therefore that a restricted-distribution system is less competitive at the intrabrand level than an unrestricted system. This would amount to saying, without any basis in fact or theory, that the services that restricted distribution encourages are inherently less important-to the consumer, the courts, or the framers of the Sherman Act-than the physical product with which the services are sold, even though the product may be worth much less to the customer without the services than with them.

One even can argue that restricted distribution is a more com-

ss There is service competition even under a system where each dealer or distributor has an airtight exclusive territory. The possession of a monopoly will cause the dealer or distributor to convert potential monopoly profits from charging a monopoly price into expenditures on greater service competition, thus attracting more customers. If it does not do this, the manufacturer will award the dealership or distributorship to someone who will, because the manufacturer has no incentive to confer monopoly profits on its dealers and distributors. This is an example of competition for the market, rather than in the market. It is genuine competition nonetheless. See, e.g., Demsetz, Why Regulate Utilities?, 11 J.L. \& Econ. 55 (1968). For judicial recognition of the concept of competition for a market, see United States v. EI Paso Natural Gas Co., 376 U.S. 651 (1964).

so United States v. Socony-Vacuum Oil Co., 310 U.S. 150, 226 n.59 (1940).

57 United States v. Container Corp. of Am., 393 U.S. 333, 337 (1969). This expression is rendered ambiguous by the use of the term "free market forces." 
petitive method of providing services at the level of wholesalers or retailers than the alternative methods that might be used if restricted distribution were forbidden. For instance, one way a manufacturer can get a retailer to provide a service that would enhance the value of his product, but that the retailer is reluctant to provide because of the free-rider problem, is to pay the retailer to provide it. This would require the manufacturer to police the retailer's compliance with its agreement to provide the service. In contrast, restricted distribution uses competition to induce the retailer to provide services. The fixing of a minimum retail price, for example, induces the retailer to provide more services in order to attract sales from other retailers-that is, to compete.

This argument must not be pushed too far. If a cartel fixes prices, it encourages each member of the cartel to increase the quality of his product, reduce delivery times, provide more services, and otherwise step up nonprice competition in order to take sales away from the other members of the cartel. One should not conclude from this that a cartelized market is as competitive as a noncartelized market, though in different ways. The paradox stems from the ambiguous meaning of "competition." It can be viewed as a process, and equated with rivalry, in which event a cartelized market is as competitive as a noncartelized market (even if all the competition is channeled into efforts to become a member of the cartel). Or it can be viewed as a particular consequence of a particular kind of rivalry, namely, the allocation of resources that is brought about when firms are not allowed to collude or predate. If the latter sense of competition is used, there is a clear difference between the transformation of price into service competition that occurs in many cartels, and the transformation of price into service competition that occurs when a manufacturer imposes price or nonprice restrictions on his distributors and dealers. In the former case, a misallocation of resources results-consumers pay higher prices and get more services than they really want-while in the latter case the consumers get their preferred mix of price and service.

Even if, contrary to my argument, a restricted distribution system could be regarded as inherently less competitive at the intrabrand level than an unrestricted system, there is the difficult problem of assessing the contribution of restricted distribution to interbrand competition. Again the very nature of this undertaking is ambiguous. Is the interbrand market more or less competitive if, as a result of the widespread use of restricted distribution, the 
product sold in that market is more expensive, at least in nominal terms, than it would be if distribution were unrestricted but fewer services were provided?

There is a method, suggested in my previous article on $\mathrm{Syl}$ vania, by which to determine whether a restriction on distribution has increased competition. This method is usable, however, only if competition is evaluated (as I have just argued that it should be) by its consequences-namely, by whether it produces the consumer's preferred quality-price mix of a product-rather than by the presence or absence of a particular type of rivalry, namely, price competition. The method involves a determination of whether the restriction caused the firm's output to rise or fall. ${ }^{\mathrm{s}}$ If its output expanded, the restriction must have made the firm's product more attractive to consumers on balance, thereby enabling the firm to take business from its competitors. This is an increase in interbrand competition and hence in consumer welfare, which is the desired result of competition. The increase must exceed any net reduction in intrabrand competition considered in both its price and service aspects. Any reduction in intrabrand competition, viewed by itself, would increase the price to the consumer and hence make the product less attractive to him. If, on balance, the product is more attractive to consumers, as demonstrated by the fact that more of it is sold, the net effect of the restriction on competition must be positive.

My suggested test, while easy to state and, I think, correct in principle, is difficult to apply by the methods of litigation. It requires controlling for the effects on the firm's output of exogenous factors, that is, those unrelated to the challenged practice itself. There are statistical methods for doing this, but they are not foolproof in application, nor are they easy for judges and juries to understand. Some of these difficulties can be avoided by restating the test in terms of market share rather than output; this will automatically hold constant factors affecting output that are not specific to the particular firm in question. The problem with this restatement is that if restricted distribution is adopted by all or most of the firms in a market, its benefits will not be reflected in a change in market shares, but rather in an increase in the output of all of the firms in the market, as they take sales from other products by offering consumers more services or at lower cost. My main

se Sosner, supra note 7, at 18-19. 
point, however, is unrelated to the details of the suggested test; it is that unless competition is defined in terms of consequences, there is no way to measure it for purposes of applying a balancing test.

\section{What Is to Be Done?}

The judicial performance since Sylvania has not vindicated the particularized case-by-case approach to the lawfulness of restrictions on distribution that the Supreme Court invited the lower courts to take. Because the courts have made no progress toward a definite legal standard, considerable legal uncertainty continues to surround restricted-distribution systems, and some, probably many, procompetitive restrictions on distribution are deterred by that uncertainty. Results would be improved if the courts applied a threshold market-power requirement in such cases, or required the plaintiff to prove an actual reduction in output or market share due to the challenged restriction, but for reasons already given I do not think that these reforms would solve the problem of uncertainty.

At the same time, in no case, even in the post-Sylvania period, when courts have required or at least permitted a deeper exploration of the facts than in the Schwinn era of per se illegality, has a purely vertical restriction on competition been shown to be anticompetitive. The qualification is important. The district court in Eiberger found a horizontal price-fixing conspiracy among Sony dealers, ${ }^{59}$ and the allegations in Cernuto, if true, ${ }^{60}$ also suggest a horizontal conspiracy. ${ }^{81}$ But cases in which dealers or distributors collude to eliminate competition among themselves and bring in the manufacturer to enforce their cartel, or in which vertical restrictions are used to enforce a cartel among manufacturers, can be dealt with under the conventional rules applicable to horizontal price-fixing conspiracies. They are not purely vertical cases, and they would be decided the same way even if purely vertical restrictions were legal per se.

The apparently nonexistent case is where a truly unilateral imposition of restricted distribution by the manufacturer-not as a result of pressure from price-fixing distributors or dealers, and not

s8 459 F. Supp. at 1284.

60 See note 30 supra.

61595 F.2d at 168. 
as part of a price-fixing agreement with its competitors-results in less competition in a useful sense of that word. The absence of such cases is consistent with economic theory, which teaches that a manufacturer will (unilaterally) restrict distribution only in order to be more competitive. It gains nothing by reducing competition in the distribution of its product, though it may gain from redirecting that competition from price to service.

In these circumstances, there is a strong case for that most rarely used of antitrust techniques, the rule of per se legality. ${ }^{62} \mathrm{I}$ do not know why the device of declaring a practice legal per se is so rarely used. The same considerations of judicial economy and legal certainty that justify the use of per se rules of illegality in some cases justify the use of rules of per se legality in others. Given the absence of either theoretical or empirical grounds for condemning purely vertical restrictions as anticompetitive, to declare vertical restrictions in distribution legal per se would serve both to lighten the burden on the courts and to lift a cloud of debilitating doubt from practices that are usually and perhaps always procompetitive.

The case for such a rule is not based on a disbelief in the existence of dealer cartels in which manufacturers are sometimes involved, and the adoption of the rule would not place such cartels, and the manufacturers' involvement in them, beyond the reach of the antitrust laws. ${ }^{6 s}$ There is at least one reasonably well-authenticated dealer cartel case, ${ }^{64}$ and although it is not a restricted-distribution case it illustrates the possibility of dealer cartelization; such cartelization could be facilitated by such a restriction. Dealer cartels have been alleged and found in other cases. ${ }^{65}$ Nevertheless, the

e2 The closest thing to a rule of per se legality in antitrust that comes to my mind is the Colgate doctrine, which allows a nonmonopolistic manufacturer to suggest a retail price and terminate a dealer who does not adhere to it. See United States v. Colgate \& Co., 250 U.S. 300 (1919). Relatively little is left of the doctrine, as a practical matter, after the cases cited in note 27 supra (and others like them), and I am hard pressed to think of another example where a practice has been declared per se legal. To be sure, some practices are unlikely to be found unlawful, but that is a different point.

-s A manufacturer that agreed to enforce a dealer's cartel would, of course, be liable along with the dealers as a coconspirator.

- See Eastern States Retail Lumber Dealers' Ass'n v. United States, 234 U.S. 600 (1914), discussed in R. PosNER, supra note 7, at 208-10.

cs See, e.g., United States v. General Motors Corp., 384 U.S. 127 (1966); Eiberger v. Sony Corp. of Am., 459 F. Supp. 1276 (S.D.N.Y. 1978), aff'd on other grounds, 622 F.2d 1068 (2d Cir. 1980). It is important to emphasize, however, that an agreement among dealers, such as to enforce a location clause, should not be equated with a price-fixing agreement. It is not concerted action that the antitrust laws condemn, but concerted action to 
paucity of cases seems a fair clue to the infrequency of dealer cartels relative to other antitrust violations. There are good reasons why they should be rare. Retail and wholesale trade are unconcentrated, so effective cartelization is difficult. Entry into these trades, especially by manufacturers seeking lower-cost distribution of their goods, is generally cheap and rapid, and this would make it difficult for wholesalers or retailers to maintain a cartel price for any length of time.

I do not propose the elimination of the antitrust prohibition of dealer cartels. They appear to be rare, however, and their use of a nominally manufacturer-imposed restriction seems rarer still. Hence there is little to lose in the way of effective antitrust enforcement if we require all such cases to be brought as dealercartel cases (with the manufacturer liable as an accessory) and abolish vertical restraints in distribution as a separate antitrust category.

I would, of course, apply the suggested rule of per se legality in price as well as nonprice cases. I see no obstacle to this result in the recent repeal of the fair-trade exemption. ${ }^{68}$ This repeal is not the consequence of, nor does it necessarily imply, a congressional determination that resale price maintenance shall not be subject to evolving antitrust standards that may in some cases warrant declaring a practice per se legal.

If my suggestion were adopted, difficult borderline cases would remain unresolved-cases like United States $v$. Sealy, Inc. ${ }^{67}$ and United States v. Topco Associates, Inc., ${ }^{88}$ which involved neither vertical restraints nor price fixing; ${ }^{6 \theta}$ cases like United States $v$. General Motors Corp., ${ }^{70}$ and perhaps Eiberger, involving concerted activity among dealers but possibly only in response to a free-rider problem and not in an attempt to fix prices; and cases, perhaps also illustrated by General Motors and Eiberger, where the manufacturer may have been seeking to obtain greater services and the dealers seeking to fix prices. ${ }^{71}$ These problems of classification led

reduce output (or, what is the same thing, to raise prices).

se See text and note at note 17 supra.

o7 388 U.S. 350 (1967).

405 U.S. 596 (1972).

69 See Posner, supra note 7, at 9-10.

70384 U.S. 127 (1966).

21 The facts in General Motors suggest that GM may have been a reluctant participant in the efforts of the Los Angeles Chevrolet dealers to prevent violations of the location clause in the dealership's agreement. See 384 U.S. at 133-35. On the other hand, the clause 
me in my previous article to suggest that, rather than attempting to distinguish between good and bad restrictions on distribution by whether they are vertical or horizontal, courts should inquire whether the manufacturer's output increased or decreased as the result of the restriction and therefore whether the restriction increased or reduced competition on balance. ${ }^{72}$ I now think that it would be best to declare that purely vertical restrictions on intrabrand competition, price or nonprice, in which there is no evidence of horizontal concert of action among dealers or distributors, are legal per se. ${ }^{73} \mathrm{I}$ would decide the legality of horizontal agreements by the more complex test proposed in my previous writings. ${ }^{74}$

A conclusion that all purely vertical restrictions in distribution should be legal per se does not entail that all restrictions in distribution having a horizontal element should be deemed illegal per se. There is a tradeoff between having a simple rule that would yield substantively unsound results in some cases and a more complex rule that might allow some dealer cartels to escape under a Rule of Reason analysis. Despite the difficulty of dealing with this class of cases-and it would be a larger class than it is now if purely vertical restrictions were declared legal per se, because plaintiffs would strive all the harder to characterize restrictions in distribution as horizontal-the approach I have suggested of declaring purely vertical restrictions in distribution legal per se would both simplify the law and make it economically more rational.

I am under no illusion that so radical a proposal as declaring purely vertical restrictions on distribution legal per se is about to be adopted. The price shibboleth alone militates against that result, at least for the foreseeable future. Sound interim measures include not only the concept of a market-power threshold that the plaintiff in a restricted-distribution case must cross, $^{75}$ and the idea

was in the agreement, so GM presumably had some interest in seeing it enforced. I repeat my caveat, see note 65 supra, that an agreement among dealers to enforce a location clause is not the equivalent of a price-fixing agreement, although neither should the existence of the clause immunize a dealer price-fixing agreement from antitrust attack.

72 See Posner, supra note 7, at 19-20. See also text at note 58 supra.

73 This position is similar to Professor Bork's. See Bork, Vertical Restraints: Schwinn Overruled, 1977 Sup. Cr. REv. 171, 190-91.

74 See generally Posner, supra note 7.

${ }^{78}$ I should note that having substantial market power (and I leave for another day the question, "how substantial?") is only a necessary and not a sufficient condition for condemning a restriction on distribution. A monopolist might restrict distribution in order to shift the demand curve for its product to the right, by providing greater services with the product to the consumer, and if so the restriction would enhance consumer welfare. Indeed, 
that a price restriction is lawful when it is part of a system of reasonable vertical restrictions on distribution, but also the requirement that the plaintiff in every restricted-distribution case establish the impact of the alleged restrictive practice on the defendant's output or market share. If that impact is positive, that is, if the defendant's output or market share rises as a result of the restraint, then, on balance, the restraint must promote consumer welfare and economic efficiency, and it therefore should not be found illegal.

it would increase competition, because the "monopolist" could expand the demand for his product only by inducing the consumer to switch from other products or services. Consistently with this analysis, the court in Newberry v. Washington Post Co., 438 F. Supp. 470 (D.D.C. 1977), allowed a firm found, somewhat implausibly, to be a monopolist to restrict competition among its distributors. 